\title{
Theuth Versus Thamus: The Esoteric Plato Revisited
}

The distinction between esoteric and exoteric readings of Plato will be revisited in this article with respect to two esoteric approaches: the German Tübingen School and the American Straussians (i.e., those interpreters who have been inspired by the work of Leo Strauss). There appears to be a joint motivation for these two approaches, namely, the critique of writing in the dialogue Phaedrus and especially Socrates' objection that the written text speaks indiscriminately to every audience. While the Straussians claim that the Platonic dialogues are exempt from the critique because they exhibit the flexibility of oral speech, the Tübingen School relates the dialogues to an unwritten Platonic doctrine. In this article, I argue that both approaches rightly alert us to the significance and complexity of the critique of writing, yet provide one-sided readings which do not consider all of Socrates' arguments and neglect the positions ascribed to Theuth and Thamus. When the different arguments are taken into account, the ambiguity of writing is revealed which does not allow for simple solutions concerning the status of the Platonic dialogues as written texts.

The distinction between esoteric and exoteric readings guides one of the most fundamental controversies about how we should interpret texts; the predominant battle grounds for this controversy are the Platonic dialogues. In his Lectures on the History of Philosophy, Hegel writes: "Another difficulty is supposedly this: one distinguishes between exoteric and esoteric philosophy. Tennemann ${ }^{1}$ states (Vol. II, p. 220): 'Plato makes use of this same right, to communicate only as much as he deemed advisable, and only to those whom he considered receptive.' How naïve! It appears as if the philosopher was in posession of his ideas like external objects. However, thoughts are of an entirely different nature. The philosophical idea, to the contrary, owns the human being. When philosophers explicate philosophical subject-matters, they have to follow their ideas; they cannot keep them in their

\footnotetext{
${ }^{1}$ W. G. Tennemann, to whose work History of Philosophy (vol. II) Hegel is referring here, is also mentioned by Szlezák as one of the earliest German representatives of the esoteric approach (PSP, 327).
} 
pocket." ${ }^{2}$ Hegel is cited here because he brings up an argument against esoteric readings of Plato which is more convincing than many twentieth century objections. In this passage, Hegel conveys an important insight - leaving the polemical style aside - which is quite convincing from a phenomenological perspective: we do not own our ideas, but our ideas come to us; this is one of the decisive differences between ideas and objects. It would even be justified to say that the philosophical idea "owns" the human being because it holds us in its grip, haunts us, does not let go. Therefore, Hegel considers it naïve and inappropriate to assume that philosophers hold certain ideas back while presenting others.

At the same time, the possibility of keeping a secret also needs to be acknowledged; keeping a secret is a human possibility, and we are certainly aware that keeping a secret never means the same as keeping an external object well hidden. Would the possibility of keeping secrets not undermine Hegel's remark or prove it to be merely polemical? The statements which we keep as secrets usually concern facts or specific occurrences in the world and are thus quite different from philosophical ideas. Furthermore, a philosopher would usually be so compelled by his or her ideas that a very strong reason would be needed for not showing them. In the case of Socrates, even the prospect of death was no deterring factor. However, some proponents of the esoteric approach in the twentieth century, especially Leo Strauss, suggest that Plato would hide certain ideas for political reasons or perhaps because of Socrates' destiny.

In this article, two main esoteric approaches will be briefly introduced: the so-called Tübingen School (H.J. Krämer, K. Gaiser, T.A. Szlezák, etc.) and the Straussians (L. Strauss, S. Benardete, S. Rosen, etc.). "Straussians" is an expression used here simply to refer to those interpreters who have been influenced and inspired by the work of Leo Strauss. The fact that two very significant esoteric approaches emerge in the twentieth century, one in Germany, the other in the United States, confirms the significance of the esoteric/exoteric distinction. The two approaches cannot be compared in this article in any comprehensive sense, but will be examined with respect to their treatments of the critique of writing. It will turn out that the

\footnotetext{
${ }^{2}$ Vorlesungen über die Geschichte der Philosophie II, 21: "Eine andere Schwierigkeit soll die sein: man unterscheidet exoterische und esoterische Philosophie. Tennemann sagt (Bd. II, S. 220): >Platon bedient sich desselben Rechts, nur so viel, als er für gut fand, und nur denen mitzuteilen, welchen er Empfänglichkeit zutraute. (..)< Wie einfältig! Das sieht aus, als sei der Philosoph im Besitz seiner Gedanken wie der äußerlichen Dinge. Die Gedanken sind aber etwas ganz anderes. Die philosophische Idee besitzt umgekehrt den Menschen. Wenn Philosophen sich über philosophische Gegenstände explizieren, so müssen sie sich nach ihren Ideen richten; sie können sie nicht in der Tasche behalten."
} 
Tübingen School and Straussians give one-sided readings of this critique, focusing mostly on just one of the arguments put forth. The different ways in which this argument is interpreted accounts for some of the significant divergences between the two approaches. While the two esoteric approaches share their focus on the author and audience of the written text, the Straussians conclude that the Platonic dialogues have the "flexibility" of oral discourse if they are read in the appropriate manner. The Tübingen School, in contrast, is famous for its investigation of an unwritten doctrine while still trying to give room to the written dialogues. This article will come to conclude that both suggestions are untenable due to the ambiguity of the written text which the critique of writing reveals.

Let me be clear from the outset about the fact that I deem the esoteric/exoteric distinction important and value the contributions made by the Tübingen School and the Straussians. Although several problems will be identified in the course of this article, the response cannot be to deny the esoteric/exoteric distinction or fall back behind it, as many analytic interpretations tend to. Strauss rightfully insists that it is dissatisfying and illegitimate to abstract from the dialogical format and read the statements made in the dialogues as constituting Plato's position, a position which could then be dissected into arguments $(C M$, 50). ${ }^{3}$ Instead, a response to the problems of the esoteric approaches needs to go through the esoteric/exoteric distinction, as it were. My interest lies with the motivation for the esoteric/exoteric distinction (which appears to be a joint one for the Tübingen School and the Straussians) and with examining how convincing the description of the distinction and the interpretative conclusions are. ${ }^{4}$

\footnotetext{
${ }^{3}$ Rosen describes the predominant Plato scholarship during the times when he first developed his interpretative approach in the following way: "On the one hand it was held that Plato must be read as a child of his time, in accord with the hermeneutical presuppositions of the Geisteswissenschaften. On the other hand, the actual text was disregarded by the leading English-speaking scholars, who sought to extricate from the literary ornamentation a set of arguments, to be checked for logical validity by translation into the languages of formal set theory and predicate calculus or informal natural language semantics" (Rosen (1987), xi). Although the statement that analytic scholars "disregard" the actual text would better be formulated as "disregard whole portions of the text" (i.e., those which can be considered "literary ornamentation"), Rosen here points quite rightfully to the problem that an analytic reading cannot attend to the dialogue format, has severe difficulties when faced with the Platonic myths, and is forced to give an interpretation of the critique of writing which disregards writing's essential ambiguity.

${ }^{4}$ The two approaches can only be examined here in a brief and somewhat simplified fashion; book-length studies about each of them could be (and indeed have been) undertaken. The most representative literature of the Tübingen School can be found in Krämer (1959), Gaiser (1968 \& 1980) and Szlezák (PSP). For a recent investigation of this movement, see Villers (2005) who shows how Szlezák's approach makes up for several shortcomings of the original formulations in Krämer and Gaiser.
} 
After outlining these two approaches by sketching some of their main claims and differences, the third part of the paper will examine how the esoteric approaches are based on interesting, yet somewhat one-sided or selective readings of the critique of writing in the Phaedrus. The fourth part will take up some neglected passages and arguments concerning the critique of writing. It will turn out that the dialogue gives a more balanced picture of writing and, albeit indirectly, reveals some of its strengths. Rather than forcing us to choose between the possibilities and dangers of the written text, writing turns out to be an essentially ambiguous phenomenon.

\section{The Tübingen School}

Usually, the position of the Tübingen School is identified with the search for Plato's "Unwritten Doctrine" (as the title of Gaiser's book has it). This search is motivated by Plato's critique of writing in the Phaedrus, combined with the Seventh Letter (the authenticity of which seems reasonably reliable, although there is still some dispute) which states: "On this account no sensible man will venture to express his deepest thoughts in words, especially in a form which is unchangeable, as is true of written outlines" (343a). The first authors of the Tübingen School, Krämer and Gaiser, turn toward ancient authors who hint at certain Platonic doctrines (such as Aristotle's remarks about a Platonic lecture "On the Good" as reported by Aristoxenus ${ }^{6}$ ). While it is interesting and thought-provoking that there seem to be certain clashes between the positions outlined in the dialogues and the Platonic doctrines as summarized, hinted at, or criticized by other ancient authors, it is obviously quite dissatisfying and methodologically unstable to turn away from the dialogues (or turn to them mainly in order to point to inconsistencies with the "unwritten doctrine"). Furthermore, Plato is far from presenting one definitive position in the dialogues.

Leo Strauss has presented his readings of Plato in a variety of studies, such as Strauss $(C M, P A W, S P P, A A P L)$. The most important text by Seth Benardete, for our purposes, is the interpretation of the Phaedrus (RMP). Stanley Rosen lays out his approach quite well in Plato's Symposium and explains in his recent Plato's Republic how his reading of the Republic differs from Leo Strauss' while still continuing the Straussian inspiration.

${ }^{5}$ Gaiser (1968). Both Krämer and Gaiser were students of Wolfgang Schadewaldt's; for a explanatory as well as criticial presentation of the original Tübingen School as a movement, see Gadamer (1968).

${ }^{6}$ Aristoxenus, Elementa harmonica II, 30-31. According to Aristoxenus, this lecture contained the statement "Good is One" (which, as such, does not stand in conflict with the dialogues). For a translation and discussion of Aristoxenus' text, see Gaiser (1980). 
In response to these difficulties and the criticism raised against the Tübingen School, Thomas Alexander Szlezák develops the Tübingen School approach by attending exactly to and interpreting the dialogues against the background of the critique of writing. Szlezák provides a brief definition of the esoteric approach as "conveying knowledge in a way which is strictly orientated toward the needs of the addressee" (streng an den Bedürfnissen des Adressaten orientierte Art der Erkenntnisvermittlung) (PSP, 406). This would indeed be a plausible interpretation of and response to the observation that the written text is vulnerable to misunderstandings because it cannot choose to whom it speaks. At the same time, the difficulties of an esoteric approach, especially if it wants to take Plato's written dialogues seriously, already shine forth in this definition: how can a written text convey "knowledge in a way which is strictly orientated toward the needs of the addressee"?!

In the current article, the Tübingen School will be embodied predominantly by the work of Szlezák as an advanced representative. This has several advantages. Taking a more advanced representative of a certain school often means to take a certain position in its strongest or most convincing position, especially if the potential and actual criticism of this position has already been incorporated. This is undoubtedly the case for Szlezák; he engages explicitly with the criticism raised against the Tübingen School, especially by the prominent Anglosaxon interpreter Gregory Vlastos, and he also discusses the dialogue theory based on Friedrich Schleiermacher's work from which the Tübingen School distances itself. Furthermore, Szlezák's approach is presented in a very clear and accessible fashion, and his monograph Platon und die Schriftlichkeit der Philosophie presents his (methodological) standpoint, his engagement with the critique, an exemplary interpretation of various dialogues, including the Phaedrus, and several appendices in which the standpoint is defended against various charges. ${ }^{7}$

At the same time, the advanced state of Szlezák's position might harbor a disadvantage since his standpoint is already a compromise which has emerged through the engagement with the criticism and counter-positions. It is a bit surprising, for example, that Szlezák names the dialogue theory emerging from Schleiermacher as the most important counter-position, yet states in his Preface that his approach is "based on Schleiermacher's

\footnotetext{
${ }^{7}$ Most helpful, to my mind, is Appendix I ( $\left.P S P, 331-75\right)$ which discusses the modern dialogue theory by way of ten critical theses, showing various inconsistencies in its theoretical assumptions (a few of which are mentioned in this article).
} 
dialogue hermeneutics, except for Schleiermacher's unexamined anti-esoteric premise" (PSP, VI). In other places, this statement is qualified. It appears that Szlezák agrees with Schleiermacher concerning the significance of the dialogues and the necessity of undertaking a close reading of those. His disagreement with Schleiermacher emerges with Schleiermacher's criticism of an esoteric reading of Plato and takes a more distinct form as Szlezák argues that Schleiermacher engages in (overly) subtle individual observations presumably paying too much attention to detail - and provides an impression of a reflective approach while actually being rather "naïve" $(P S P, 22)$.

In a more detailed examination close to the end of his book, Szlezák engages with a number of problematic assumptions and consequences of the dialogue theory. The points which strike me as most plausible concern the failure of reading the critique of writing carefully enough and in detail, and the difficulties which emerge from overemphasizing the dialogue form thus taking the 'early dialogues' as exemplary (PSP, 337, $347 \mathrm{ff}$.). The focus on the dialogue character creates a need to dismiss some of the 'middle' and 'late' dialogues, or to read them against the grain. Unsurprisingly, there appears to be a tendency in dialogue hermeneutics to downplay the significance of the critique of writing and to claim that the dialogue form chosen by Plato evades the criticism. Szlezák defines what he describes as dialogue theory through the "minimal consensus" that the Platonic dialogue can replace the oral conversation or is at least in a substantially better position of doing so than all systematic presentation of philosophy (PSP, 332). While such a claim reflects the general observation that Plato wrote dialogues despite criticizing writing, it seems indeed impossible to distill such a thesis about the dialogue form from the Phaedrus; in that sense, Szlezák's critique of Schleiermacher is justified. However, when we look at Szlezák's own interpretation of the critique of writing and the Phaedrus more generally in the third section on this article, it will turn out that his interpretation also harbors certain problems.

The details of Szlezák's engagement with Schleiermacher's dialogue hermeneutics, which identifies various problems and inner contradictions, cannot be discussed here. One of the inconsistencies concerns a "latent esoteric tendency" (PSP, 368) in Schleiermacher's own interpretation because Schleiermacher states that "the only way in which the talk of esoteric and exoteric might be used here" would refer to the reader and his or her ability to attend to 
the indirect or inner messages of the dialogues. ${ }^{8}$ According to Szlezák, this esoterism of reading presupposes the esoterism of writing. A careful reading is possible and necessary, according to Szlezák, only because Plato wanted to conceal certain messages from the superficial reading. This argument does not convince me; the conclusion that Plato wanted to hide something or deemed the true message of his writing only suitable to "a few" who are capable of developing a "secret interpretation" (PSP, 368) by no means immediately follows from Schleiermacher's remark. Szlezák makes a statement about the author's intentions, ascribing to Plato an intention of consciously wanting to hide something. Schleiermacher's statement, in contrast, describes a general hermeneutic principle according to which we always interpret when we read a text, and the more carefully we read, the deeper our understanding.

This controversy marks an interesting opposition since Szlezák attributes an "inner esoterism" (PSP, 368) to Schleiermacher. Such an inner esoterism would indeed just be a different way of formulating the hermeneutic principle, and it seems that Schleiermacher does not deem the formulation "esoteric" particularly useful, but states that if this term should be used and make sense at all, it would need to be used in the way he describes. Szlezák, in contrast, and ultimately the Tübingen School in general, is concerned with what could be called an 'outer esoterism' which relates mostly to the author. A certain careful attitude of the reader is required only as a result of and direct response to this 'outer esoterism.' It seems immediately obvious that such an 'outer esoterism' is much less stable and involves several assumptions about the author. ${ }^{9}$

\footnotetext{
${ }^{8}$ Schleiermacher (1969), p. 16.

${ }^{9}$ These problems are indirectly addressed in a footnote which Szlezák directs at H. Meißner's Der tiefere Logos Platons. Eine Auseinandersetzung mit dem Problem der Widersprüche in Platons Werken. Heidelberg: C. Winter, 1978. interpretation of Plato, but which, interestingly, appears to hold just as well and perhaps more so for the Tübingen School. Szlezák identifies an error of logic in an argumentation which aims at a "deeper" interpretation of Plato's texts.

Statements about the text ('Plato means A here, not B') are not being separated from evaluating statements about such statements ('It is the deeper interpretation that Plato means A here and not B'), but are systematically conflated such that one's own assessment is attributed to Plato, for no reason, such that a type of statement emerges which appears to speak about the text, but instead contains a hidden self-evaluation ('Plato means here that A is the deeper logos of this passage, even though he places B on the surface for the majority of readers'). (374, F. 77)

This appears to be exactly the procedure and flaw of the Tübingen School, and especially of the version which Szlezák proposes. The esoteric approach itself is based on attributing hidden intentions to Plato (which, as we will see in the third section of this essay, cannot be deduced from the critique of writing). The reading suggested by the Tübingen School has to presume that 'Plato means here that A is the deeper logos of this passage, even though he places B on the surface for the majority of readers.' Szlezák accuses Meißner of failing to separate
} 
The true justification of an esoteric reading can only be accomplished with respect to specific dialogues, of course, and Szlezák provides his own, not uncontroversial reading of the Phaedrus to which we will return below. General methodological considerations as we have discussed them up to here are naturally more vulnerable to criticism, and it has even been argued (e.g., by Hegel) that a method can never be explained and justified in abstraction from its subject-matter. At the same time, Szlezák does not really attempt to outline a methodology of reading, also given his suspicions against hermeneutics. He is mostly arguing against the designated counter-position, the dialogue hermeneutics inspired by Schleiermacher.

The controversial discussion of certain assumptions, convictions and conclusions of dialogue hermeneutics which Szlezák undertakes is certainly revealing in many ways and points to problems which emerge when overstating the dialogue character of Plato's work to the extent that written dialogues appear exempt from the critique of writing altogether. However, Szlezák creates problems for his own approach which inevitably emerge when a certain position is defined mostly by way of contrasting it with a different one: the rejected position comes to indirectly determine the new position. Since Szlezák even tries to integrate some elements of Schleiermacher's theory into his own approach, it becomes even more difficult to discern his esoteric approach as such. ${ }^{10}$

More internally consistent appears the original theory of the Tübingen School. Yet an approach to Plato which requires turning away from the Platonic dialogues (and concentrating instead on short, rare, and overall not very elucidating remarks of other ancient authors) cannot be the final response. Rather, Szlezák's integrative reading has a number of advantages. He returns us to the Platonic dialogues and alerts us to the importance of settings and characters. He urges us to read carefully and to allow for a reading on different levels.

between his own assessment and Plato's intended meanings - but which reading could ever be entirely sure of having found Plato's true intentions, especially under the assumption that Plato was purposefully hiding the deeper logos?

${ }^{10}$ One instance where this conflict emerges is Szlezák vehement rejection of Vlastos' criticism concerning Krämer, for the reason that Vlastos attributes to Krämer the position that Plato would write "false" statements when Krämer does not use the designation, "false." Yet at the same time, Szlezák maintains (and unfortunately does not explain or elaborate) that Plato may have "held back certain important insights" (PSP, 340). A closer investigation of this difference would be very useful. From a phenomenological perspective, it is clear that making a "false" statement differs from "withholding" certain parts of information. Yet how does this distinction become manifest in Plato's dialogue? And how do we make sure that we read a certain statement as withholding a deeper message rather than as a false statement? How can we avoid making the logical mistake which Szlezák describes, the mistake of attributing our own evaluations to Plato? 
Furthermore, both his interpretations of the dialogues and his more general considerations are characterized by impressive clarity. Although it has turned out that neither his criticism of Schleiermacher's dialogue nor his (somewhat dispersed) presentation of his own reading are fully convincing, the task of reading the Platonic dialogue with attention to frame, setting, and characters, and of distinguishing between different levels, remains important. One of the problems emerging from Szlezák's approach is his unwillingness to focus on the level of reading, and instead focus on the level of writing, author's intentions, or what I have called 'outer esoterism.'

Before turning to Leo Strauss and his version of the esoteric approach, let me point to a certain blindness in Szlezák's reading of Leo Strauss. In Platon und die Schriftlichkeit der Philosophie, Strauss is mentioned twice, in potentially opposite ways. Strauss (and A. Bloom, J. Klein, S. Rosen, where only the latter is really a Plato interpreter) is first mentioned without any specific explanation or argument - as an American version of Schleiermacher's dialogue theory (PSP, $331 \&$ Fn. 3, 332). Yet later on, Strauss and the interpreters influenced by him are given as a rare example of modern interpreters who stay clear of attributing the modern will toward complete transparency to Plato (PSP, 367). This tension in Szlezák's interpretation of Strauss and the Straussians is symptomatic of a tension which also occurs within Szlezák's own methodology as he tries to integrate insights from the dialogue theory.

While the Straussian reading of Plato also makes use of the esoteric/exoteric distinction, one important difference to the Tübingen School lies in the fact that Leo Strauss never attempted to search for an unwritten doctrine outside of the dialogues. This has been a further motivation to focus on Szlezák in this article, who returned the Tübingen School to the dialogues, as it were, and whose approach is thus closer to Strauss than Krämer and Gaiser could be.

\section{The Straussians}

Leo Strauss is a complex and controversial writer. We will not be concerned here with his political theory, but as much as possible only with his Plato interpretations, and more 
specifically, with his way of approaching Plato. ${ }^{11}$ A couple of difficulties emerge right away: we cannot engage in detail with Strauss' readings of specific dialogues except for certain exemplary moments and the one passage most relevant for our purposes, namely, the critique of writing. Therefore, some of Strauss' general comments on writing and reading will need to be considered to obtain a sense of how he reads Plato; but those considerations usually relate to the history of philosophy in general and perhaps even to all written texts. Unlike the Tübingen School authors, Strauss is not exclusively a Plato scholar, which does not take from his impressive familiarity with the Platonic dialogues in the least. Another problem which will emerge with respect to Strauss' interpretation of texts concerns the fact that he does not consider them from a strictly philosophical but rather from a political or sociological perspective.

Strauss suggests developing a "sociology of philosophy," and since he is aware that this is an unusual proposal which might cause resistance, he explains that "one must turn to other ages, if not to other climates" to see the necessity for such a project $(P A W, 8)$. The ages and climates to which Strauss turns are accessed through the Jewish and Islamic writings of the middle ages. This does not diminish the significance of such a sociology for our times since Strauss considers our times, or at least the twentieth century, as a time of crisis ${ }^{12}$ in which certain forms of writing might be in danger of persecution. So we can draw certain lessons from the middle ages, including the distinction between exoteric and esoteric teaching which Strauss encountered in Farabi's Plato and the writings of Farabi's successors. "Farabi's Plato informs us about the most obvious and the crudest reason why this antiquated or forgotten distinction was needed. Philosophy and the philosophers were 'in grave danger.' Society did not recognize philosophy or the right of philosophizing" (PAW, 17). Accordingly, exoteric teaching becomes the "armor" which protects philosophy such that it can appear $(P A W, 18)$.

The suggestion to consider the times in which certain philosophers were writing to determine whether they were in danger is problematic, and Strauss seems to be aware of this.

\footnotetext{
${ }^{11}$ I would like to note that those who regard Strauss as an inspiration for a strand of neo-conservatism in American politics seem to engage little or not at all with his actual texts whereas those who study his texts carefully provide good arguments against such a connection. See especially Kauffmann (1997) and (2008).

${ }^{12}$ Associations with Husserl's The Crisis of European Sciences and Transcendental Philosophy are not arbitrary: Strauss not only attended classes by Husserl and Heidegger but also engaged with them in his writings, including Husserl's Crisis (SPPP, 36 f.)
} 
This awareness might be one reason as to why he speaks of a sociology of philosophy, signifying that he is not always moving within the realm of philosophy. Nevertheless, it cannot be plausible to always examine the actual historical situation of writers before attending to their texts. For example, there are problems of access and reliability, especially where the danger or actuality of persecution is concerned: are we really able to find out who might have been persecuted? Strauss is wise enough, of course, not to suggest any such procedure, but he does describe certain ages and climates as more dangerous for philosophy. Overall, he seems to believe that we are well advised always to presume that a certain author might have been in danger of persecution, or might have written on different levels.

This holds particularly for Plato, according to Strauss: "Farabi ascribed to Plato the view that in the Greek city the philosopher was in grave danger. In making this statement, he merely repeated what Plato himself had said" $(P A W, 21)$. This statement is worth pondering for a moment. Strauss is here supporting Farabi's position by pointing out that Farabi can fall back on what Plato himself had said. It seems intuitively right that Plato indeed believed the philosopher to be in danger in the city; to state the obvious, we can barely imagine what it must have meant for him to witness the trial of Socrates. There are indeed several comments in the dialogues about the dangers for the philosopher to engage in or get entangled in political matters. ${ }^{13}$ Nevertheless the manner in which Strauss presents his argument does strike me as problematic. First, he does not provide any textual evidence for his statement at this point (and it should not be the reader's task to search for it in other texts by Strauss where some more or less direct evidence could be found). The statement opens and closes in a rather abrupt fashion, and such abruptness characterizes quite a number of Strauss' claims. ${ }^{14}$ Second, Strauss himself has criticized quite vehemently any attempt to attribute claims from the dialogues to Plato as something he 'himself had said.' Strauss goes so far as to compare the utterances of interlocutors in the Platonic dialogues to the utterances of protagonists in Shakespeare's dramas which we certainly would not read as representing Shakespeare's own standpoint $(C M, 50)$. Third, it is exactly to Strauss' credit to have pointed out that the ideal city, in the Republic, is a city founded "in speech, i.e., not in deed" (AAPL, 1). The ideal city can thus not be read as evidence of the dangers which the philosophers face in the city;

\footnotetext{
${ }^{13}$ Perhaps most prominently: Apology 32e.

${ }^{14}$ We will see below that the same holds for Seth Benardete.
} 
similar complications arise for passages about philosophy and politics in some of the other dialogues.

Overall, Strauss would perhaps argue that it does not really matter whether a certain writer was in any way endangered since our task remains the same in any case: to read as carefully as possible. ${ }^{15}$ Strauss never claims to have found the reading that would be correct and comprehensive; he states in relation to Heidegger, who appears to believe that nobody has understood him adequately: "I believe he is right, for is the same not also true, more or less, of all outstanding thinkers? This does not dispense us, however, from taking a stand toward him, for we do this at any rate implicitly; in doing it explicitly, we run no greater risk than exposing ourselves to ridicule and perhaps receiving needed instruction" $(S P P, 30){ }^{16}$ Statements like these, which exhibit a certain modesty in presenting philosophical reading as an ongoing process always in need of correction constitute an interesting supplement to Strauss' strong and daring claims about Platonic writing. This combination also makes it difficult to critique Strauss' method of reading, especially since he presents his methodology in practice rather than in theory.

One of the most famous results of Strauss' Plato interpretations also has implications for the critique of writing and the question as to how Plato should be read. The Republic, Strauss argues, does not show what a city should look like, but what it would need to look like in order to accommodate our human needs, including the erotic needs. ${ }^{17}$ Since it turns out that a city constructed in this fashion is impossible, Plato allows us instead to see "the essential limits, the nature, of the city" $(C M, 138)$. This result, which can only be presented rather than explained here, points to the clash between philosophy and politics. To put it in terms other than Strauss', politics has to accommodate the physical needs of the people and has to make

\footnotetext{
${ }^{15}$ This issue is somewhat similar to the question concerning the authenticity of Plato's writings. Drew Hyland reports having heard from Stanley Rosen that Strauss would explain to his students how our task as readers would remain unchanged even if each one of Platonic dialogues was actually written by a different author (Hyland (2008), p. 6).

${ }^{16}$ See also the following statement by Strauss, about Socrates: "The doctrine of ideas which Socrates expounds to his interlocutors is very hard to understand; to begin with, it is utterly incredible, not to say that it appears to be fantastic. (...) No one has ever succeeded in giving a satisfactory or clear account of this doctrine of ideas" $(C M, 119)$.

${ }^{17}$ Emmanuel Levinas would argue that Strauss misunderstands the nature of the erotic if he connects it with the needs for food and drink. According to Levinas's analyses, there is an essential difference between needs, such as the need for drink and food, which are satiable, and insatiable desire for the Other. Erotic love holds an ambiguous position since it has elements of need as well as desire (TI). Levinas sees his analyses confirmed in Plato's Symposium and Phaedrus.
} 
compromises because of this necessity. Politics can thus not fully adhere to philosophical principles; certain clashes between political decisions and highest principles, especially ethical principles, are inevitable. This is admittedly not quite the conclusion which Strauss draws, but the inevitable conflict between philosophy and politics has been highlighted here to show that the inextricable link between politics and philosophy which determines Strauss' readings is questionable in light of his own reading of the Republic. It might be important to examine the political situation of a writer and engage in a sociology of philosophy, but such examinations can never be sufficient for an understanding of the philosophical content. The political perspective is only one of many perspectives to be taken toward a philosophical text, and if it is highlighted at the expense of other perspectives, a one-sided picture will arise.

Strauss' interpretations bring out several interesting facets of the Platonic dialogues, and he has been more daring and more explicit than the traditional Plato scholars. Yet it is sometimes difficult to argue with his claims, especially when he does not develop them in detail. Similar considerations hold for Strauss' methodology or his interpretative approach which prove difficult to assess because he does not formulate his method as explicitly as Szlezák (who, despite giving detailed justification of his method, remains too focused on the hermeneutical counter-position, as we saw). Like the Tübingen School, Strauss assumes that Plato was hiding certain messages. While Strauss gives a more detailed account of the need for an exoteric teaching as philosophy's "armor," his account creates new problems because either it holds for all writers, or we face the complex project of determining which writers might have been potential victims of persecution. And even if we limit the focus to Plato (as the concentration of the current article), it seems an unnecessarily strong assumption to make that Plato was indeed (purposefully) hiding something in his dialogues. However, both the assumption that Plato was hiding messages and the political perspective taken by Strauss do not appear absolutely essential to the way of reading Plato which he inaugurated, or at least they are much less present in interpreters like Benardete and Rosen.

In contrast to the Tübingen School, Strauss makes some statements which place him in close proximity to Schleiermacher. Strauss considers an examination of the dialogue format essential to any reading of Plato, and with respect to the critique of writing he states: "The Platonic dialogue, if properly read, reveals itself to possess the flexibility or adaptability of oral communication" $(C M, 53)$. Like Schleiermacher, Strauss thus believes that the critique of writing does not apply to the Platonic dialogue or that the Platonic dialogue is a response to 
the precarious status of writing. Yet unlike Schleiermacher, Strauss attributes a political or sociological significance to the dialogue format: "The literary question properly understood is the question of the relation between society and philosophy" $(C M, 52)$. For Strauss, what appears to be an aesthetical question is ultimately a sociological or political one since the relation between society and philosophy determines how a writer in a given epoch can write. Here, Strauss parts ways quite radically with the dialogue hermeneutics, and the difference is also related to the emphasis on the writer rather than reader which characterizes esoteric approaches.

Slzezák and Strauss both locate the justification of the esoteric approach on the side of the writer. It is only because something has been hidden by the writer that requirements are imposed on the reader. This is the most important commonality of the two esoteric schools presented here, and at the same time, their greatest weakness, to my mind. Does it not follow from the critique of writing that questions about the writer's intention can exactly not be answered with any certainty, and that what we are left with are the written text and the reader's responsibility? The possibility of the writer conveying messages on different levels is certainly worth noting, and it is also plausible that the dialogue format can accommodate such a possibility. But both the Tübingen School and Leo Strauss appear to consider this possibility a certainty, or certain enough to let it motivate their esoteric approaches.

\section{Esoteric Approaches and the Critique of Writing}

At this point, we will abandon the more general methodological discussion and turn to a specific passage: the critique of writing. The critique of writing by way of the myth of Theuth occurs as Socrates sets out to examine a question still left open: "What's left, then, is aptness and ineptness in connection with writing" (274b). The context in which this comment arises will be bracketed for now; we will return to it in the next section. The myth goes that Theuth, a very creative divinity, invented various arts, such as the art of the number, i.e., arithmetic, but also the art of the letter, i.e., writing. As he presents the art of writing to the Egyptian king Thamus, Theuth calls it "a potion (pharmakon) for memory and for wisdom" 
(275a). ${ }^{18}$ Thamus finds himself disagreeing on both accounts. First, writing encourages forgetting since people will rely on what has been written rather than practice their memory. Thamus also points out that writing is something external whereas memory is inside us. Second, writing does not make people wiser. Thamus claims that students will be provided "with the appearance of wisdom, not with its reality" because they "will hear many things without being properly taught" (275a).

After Thamus' two objections, Socrates follows up with his own interpretation of the myth. Socrates first states that writing can only serve as a reminder for those who already know what the writing is about. He gives two arguments for this claim. First, writing resembles painting, and the written text, like a painting, is silent and signifies the same thing forever. Second, the written text "rolls about everywhere" and speaks to everybody indiscriminately. It is helpless and "always needs its father's support" (275e). Socrates continues his criticism by way of a direct comparison between speech and writing, introducing speech as the better and more capable brother of writing which avoids the pitfalls of the written letter. Phaedrus concludes that speech is "living, breathing discourse" of which the written discourse is only an image (276a).

These four arguments, two by Thamus, two by Socrates, ${ }^{19}$ summarized here in the briefest form, receive different treatment by the two schools of esoteric approaches. We will see that both the Tübingen School and the Straussians focus predominantly on Socrates' second argument; yet they do so in different ways and with different conclusions. It is not surprising that Socrates' second argument serves as the main basis for the esoteric approaches since both schools claim that it is because of the indiscriminate general audience that Plato decided to hide certain messages in his dialogues. However, this reliance on Socrates' second argument needs to be examined, both with respect to how the argument is being read and with respect to the neglected other arguments.

\footnotetext{
18 Jacques Derrida has provided a detailed and famous interpretation of the expression "pharmakon" in his "Plato's Pharmacy" (in Disseminations). I will refrain from engaging with Derrida's text in the current article because Derrida's interpretation is too complex to allow treatment in a marginal fashion, and his questions are rather different from the ones pursued in the current article. See my [removed for blind review] for a discussion of Derrida's interpretation with respect to the question of ambiguity.

${ }^{19}$ Hyland considers the final part of Socrates' explanation a third argument: written texts "cannot by themselves sustain the long dwelling together that philosophy would require" (Hyland (2008), p. 130). Yet it is not clear whether this is a further argument or rather a continuation of the comparison between speech and writing; in any case, the point appears not as important for our purposes in the current essay (and would require a more detailed interpretation, considering the nature of philosophy and dialectic).
} 
Szlezák points out that a book cannot choose its audience whereas the success of dialectic depends on picking the right partner, as Socrates emphasizes in the final part of his interpretation (PSP, 16). After interpreting the critique of writing, Szlezák asks what conclusions we can draw for reading the Platonic dialogues. He repeats again that the critique of writing provides arguments against Schleiermacher's dialogue hermeneutics and that Schleiermacher and his followers do not seem to take the critique of writing seriously. Szlezák's positive conclusions for reading the dialogues remain sketchy; one rather curious suggestion concerns a typology of dialogues and dialogue passages which would point to the fact that something is missing in the dialogues (PSP, 22). Perhaps Szlezák is so brief in his conclusions here because he realizes that a more detailed treatment would lead him to the conclusions drawn by the traditional Tübingen School and would not coincide with his intention of reading the dialogues carefully.

Notably, Szlezák points out that the interpretation of the critique of writing needs to be confirmed by or checked against the "whole of the Phaedrus" (PSP, 23). This is a very important reminder (which will also guide the interpretation provided in the next section of the current article). However, Szlezák gives a peculiar formulation of the dialogue's goal, claiming that the goal consists in "winning the young Phaedrus over for the philosophical life" $(P S P, 24)$. Szlezák then proceeds to ask what kind of person Phaedrus is: a literature buff. This formulation of the dialogue's goal provides an example of how the esoteric approach can lead to a misleading reading, to my mind. Szlezák shares with the Straussians a special focus on the dialogue setting and interlocutors. Such an emphasis is indeed helpful; yet we must not neglect the fact that we are dealing with a written dialogue, a written text, which speaks to its readers. If the dialogue was indeed just happening between Socrates and Phaedrus, Szlezák's interpretation would be quite justified: Socrates is trying to convince Phaedrus of the philosophical life. Yet it is Plato who writes this dialogue down for us, the readers, and it is thus not incidental that the speeches in the first part are about Eros and the discussion in the second part about rhetoric. The goal of the dialogue might consist in showing the connection between Eros and logos, or in showing how philosophy harbors both those elements and is itself the link between Eros and logos. The question concerning the theme and goal of the Phaedrus cannot be explored here in detail, but it should be obvious that the dialogue treats of more than the conversion of Phaedrus to the philosophical life. 
To be sure, Szlezák presents Phaedrus as the representative of a certain kind of person, not just as Phaedrus, the individual. But my point is that in the case of a written text, background information about the interlocutors and their situation can only provide additional help and material; it must not detract from the written text itself, nor must it be used like a secret 'key' to understanding the dialogue. ${ }^{20}$ When attention to interlocutors and setting is taken too far, an antiplatonic focus on specific people and events arises (- although when applied in moderation, this focus balances out the prevalent impression of Platonism as concerned with universal forms). Furthermore, if the events in the dialogues are taken as interactions between people rather than as a staged dialogue which has been written down, there is a danger of abandoning the esoteric insight that the dialogues can be read on different levels. The interlocutors are important; but if Socrates merely wanted to convince Phaedrus, it would not be worth our sustained attention.

In sum, the Tübingen School does not provide a detailed and multi-faceted interpretation of the critique of writing (and Szlezák's attempt at locating the critique of writing with respect to the dialogue as a whole is questionable, as we have seen). As already indicated before, Szlezák's attempt to combine the inspirations of the Tübingen School with a careful reading of the dialogues creates internal tensions which become manifest within his interpretations. The traditional representatives of the Tübingen School, Krämer and Gaiser, do not provide a detailed interpretation of the critique of writing because they are mainly interested in the results which emerge from combining this critique with the Seventh Letter. ${ }^{21}$ Ultimately, the critique of writing then only provides additional evidence, confirming the

\footnotetext{
${ }^{20}$ A different example of the procedure discussed here can be found in Hyland (2002). Hyland argues that, in the Phaedo, Socrates brings up proofs for the immortality of the soul because his interlocutors are mostly Pythagoreans, and because he knows that these proofs are likely to have a calming effect on them (given that they are crying about his impending death, which makes a philosophical conversation impossible). Yet here as well, the fact that we are dealing with a written text must not be neglected. The point cannot just be to convince some Pythagoreans, but to convince us - if not of the soul's immortality per se, than at least of the relevance of this topic. As Hyland himself points out in the end, the dialogues are "dialogues between Plato and $u s "$ (p. 271).

${ }^{21}$ It might appear surprising that the Seventh Letter (and the Second Letter, in which it is stated that "there is no writing of Plato's, nor will there ever be; those that are now called so come from an idealized and youthful Socrates," 314c) are not being considered in the current article. There are several reasons for this. Most importantly, a letter does not have the feature of the written text which is described as problematic in the critique of writing: it does not "roll about everywhere" but has a specific addressee. Utilizing letters for philosophical argument thus already means disregarding this fact (and it is particularly ironic that the Second Letter states that this letter should be read again and again and then burned ....). Furthermore, the letters do not play an important role for the Straussians, and since a point of contact between the Tübingen School and the Straussians is sought here to be able to relate their esoteric approaches to each other, the critique of writing in the Phaedrus provides a much more suitable connection.
} 
argument gained elsewhere (i.e., in the Seventh Letter and other ancient sources) that Plato had an unwritten doctrine outside of the dialogues. Deriving this claim from the dialogues themselves would be problematic and even create a version of the liar's paradox ("It is stated in the dialogues that the dialogues cannot be taken at face value"), and the traditional Tübingen School seems well aware of this. The conclusion drawn in the first section is thus confirmed: the traditional Tübingen School holds a theoretically more consistent position than Szlezák's, yet requires turning away from the dialogues, which is dissatisfying for various reasons.

The reading of the critique of writing undertaken by the Straussians also concentrates on Socrates' second argument, but in a rather different fashion and with different conclusions. We have already seen in the previous section that Strauss arrives at the rather optimistic conclusion that the Platonic dialogues have the flexibility of oral speech. Strauss does not really argue for or explain this thesis much; yet it is closely related to the critique of writing about which he states (just shortly before concluding that the Platonic dialogues have a response to this critique): "Plato's Socrates discusses the literary question - the question concerning writings - in the Phaedrus. He says that writing is an invention of doubtful value. (...) Writings are essentially defective because they are equally accessible to all who can read or because they say the same things to everyone" $(C M, 52)$. Since the context of this statement does not help much for clarifying it, we need to explore it for a moment to see what Strauss might be saying here. Strauss points out that the art of writing is an invention - a fact which will be discussed in the next section - and that it is of "doubtful value." This characterization might imply that writing has an ambivalent position, as Seth Benardete will conclude and as we will examine in some detail in the next section. However, it seems that Strauss connects "doubtful" to the "defective" status of writing. This defectiveness, in turn, is based on Socrates' second argument: the written text speaks to everybody in the same way. Socrates argues that this is because writing reaches "indiscriminately those with understanding no less than those who have no business with it" (275e).

Both Socrates' statement and Strauss' claim could easily be interpreted in terms of an elitist view of philosophy, such that philosophy could only reach a few and not everybody. Moreover, Strauss' formulation about the lesser value of writing might even seem to point to a moral inferiority of that which reaches everybody or the "many," and thus indirectly of the "many." However, Strauss does not use problematic expressions like the "few" or the "many" 
here, and his final argument comes at the end of the sentence: writings "say the same things to everyone." This is ultimately a pedagogical statement. There is no evidence in Strauss' writings that he deemed certain people, or most people, unable to engage with philosophical texts. $^{22}$ Rather, it seems a justified observation that different readers find themselves in different 'places' and have different degrees of philosophical preparation and hermeneutical sophistication. From Strauss' perspective, the Platonic dialogues are particularly helpful in this respect because they can address readers differently, especially on a first level of access (which some people might find through stories, others through poetry, still others through a philosophical question or controversy). The art of careful reading or hermeneutics is then a matter of practice, and Platonic dialogues help us gain such practice.

Yet Strauss' own texts, and the texts of authors like Benardete and Rosen, also require a certain effort from the reader. The criticism so often raised against Strauss and the Straussians, namely, that their texts are "opaque" and "vague" 23 is not entirely unfounded; yet it strikes me as more appropriate to describe their style of writing as abrupt. The reader is forced to engage with the claims made, either by examining an argument which is only made briefly, or even by filling in the argument for the claim. In a certain sense, the texts of the Straussians are themselves esoteric writings and ask the reader to practice by engaging with them - rather than showing in detail how an esoteric reading works. This might be a useful, but difficult exercise; it would be easier to read their interpretations if the Straussians made it more obvious whether they are summarizing, interpreting, or speculating. ${ }^{24}$

A prime example of this technique and the difficulties connected with it can be found in Seth Benardete's The Rhetoric of Morality and Philosophy. Benardete attends to the

\footnotetext{
${ }^{22}$ The problem of elitism is explained well, with references to Strauss interpreters from both sides, in Batnitzky (2006), p. 164 ff. See also Kauffmann (2008) who examines some of the widespread assumptions about Strauss and argues that Strauss' reading of Plato "never suggested to interpret the 'philosophers-kings' to be an advisable and practical political option, let alone appropriated it" into his own political theory (Kauffmann (2008), p. 88).

${ }^{23}$ These terms are used, for example, in two reviews of Stanley Rosen's Symposium: one by H.J. Easterling in The Classical Review, vol. 21, no. 3, 1971, pp. 362-64, the other by J.D. Moore in The American Journal of Philology, vol. 93, no. 4, 1972, pp. 612-16.

${ }^{24}$ The speculations can be very interesting, provided they are designated as such. For example, Strauss suggests at the beginning of his reading of the Laws that the Athenian stranger might be Socrates in a Platonic thoughtexperiment of sorts: "It thus suggests itself to us that if Socrates had escaped from prison, he would have gone to Crete, where he was wholly unknown and would have come to sight only as an Athenian stranger" $(A A P L, 2)$-because in the Crito, Socrates only states that he would not want to go to one of the well-governed cities nearby, where he would be discredited by his unlawful escape, or to Thessaly, utterly lawless; so being an "Athenian stranger" in a lawful place like Crete could have been appealing.
} 
Phaedrus and especially to the critique of writing in much more detail than Leo Strauss, and his observations are insightful and thought-provoking - yet it would be a lot easier to engage with them and build on them if Benardete elaborated on his suggestions. Especially striking is Benardete's claim that Socrates is concerned with written laws rather than written texts in general. This claim will be investigated here, despite the difficulty that Benardete does not make it quite clear how the thesis is motivated.

It is to Benardete's credit that he, unlike many other interpreters of the critique of writing, provides a reading of the Phaedrus as a whole and thus attends also to those passages which address writing outside of the myth of Theuth. Commenting on Phaedrus' question to Socrates about the potential shamefulness of writing and Socrates' response that writing is not shameful per se, but only when done badly (258d), Benardete writes: "Writing in itself is never the issue in the Phaedrus. Phaedrus makes it clear that the issue is publication, and Socrates that it is the perpetuation of writings in the form of laws and decrees" $(R M P, 157)$. To be sure, Socrates indeed brings up examples of politicians and lawgivers (Lycurgus, Solon, Darius) when Phaedrus asks him whether writing should be considered shameful. Phaedrus had raised the example of politicians (257d), and Socrates adds the example of lawgivers. In that sense, it is Socrates who brings law into the discussion. But does it follow that Socrates is only interesting in writings in the form of laws? And does it follow that the later discussion of writing, namely, Socrates' interpretation of the myth of Theuth, also deals with law?

Benardete claims that "the most sacred of writings are religious and legal" (RMP, 157), and when he discusses the critique of writing, he makes reference to the unwritten laws in Sophocles' Antigone (Ant. 454-55; RMP, 187), thus connecting the legal to the religious in the divine law. Such references are helpful for us to realize the different context of the Greeks who were certainly not surrounded by writings on an everyday basis like we are nowadays. Written laws constitute a significant and useful manifestation of writing, and in the written law, the twofold character of the law becomes manifest: legal texts are manmade, yet they also share the binding character of the divine law (but not to the same extent, as Antigone argues against Creon). The connections between writing and law are thus elucidating for an interpretation of the written text, and Benardete is right to point out that Socrates' second argument against writing is closely linked to the argument in the Statesman (294a) that law 
"by its very generality cannot cover all contingencies" (RMP, 189). ${ }^{25}$ The general accessibility of the written text and the generality of law are linked; but Benardete claims that Socrates' second objection "is in itself a criticism of the law" $(R M P, 189)$, thus holding on to his earlier claim that writing as such is never at issue in the Phaedrus.

If Benardete developed his interesting claims about the intrinsic connection between writing and law (for Socrates) more explicitly and clearly, a discussion could emerge. But since Benardete presents this connection as if it was a fact rather than an interpretation, I return to my earlier concern: the need to differentiate between summaries, interpretations, and speculations, rather than letting the reader do this work. As it stands, I remain unconvinced by Benardete's claim; it seems to me that writing as a phenomenon or the written text as such is being discussed in the dialogue and especially in the myth of Theuth, even though the written law can bring out certain features and problems more clearly. It is the phenomenon of writing to which we will now turn.

\section{The Ambiguity of Writing}

Before the critique of writing occurs, Phaedrus suddenly brings up a hearsay argument against writing, claiming that "the most powerful and renowned politicians are ashamed to compose speeches or leave any writings behind" (257d). After Socrates has reminded Phaedrus of various famous politicians and lawgivers who did not reproach writing to the least, he summarizes the results as follows: "It's not speaking or writing well that's shameful; what's really shameful is to engage in either of them shamefully or badly" (258d).

Returning now to the myth of Theuth and the objections raised against writing, some aspects will be highlighted which the esoteric readings neglect; a full-fledged analysis of the critique of writing, however, goes beyond the confines of this essay. Concerning the myth of Theuth, it is important to note the fact that writing is introduced as an invention. An invention opens up a realm of possibilities that had not existed beforehand. Often, this means that the new invention can be applied to good usage as well as bad or harmful usage. If we keep in mind Socrates' earlier conclusion that writing is not in itself anything shameful, it would

\footnotetext{
${ }^{25}$ In his interpretation of the Statesman, Stanley Rosen writes that "nomos is the least mobile of writings" (Rosen (1997), p. 158), thus presenting law as writing in the emphatic sense.
} 
appear plausible to investigate the useful as well as the harmful applications of this new invention.

Thamus' objections are not really being considered by the esoteric readings, and at first glance, they indeed appear less philosophical than Socrates' arguments. Yet the distinction between mere appearance and reality (of wisdom) in Thamus' second argument is certainly worth noting. This distinction affirms the need to read and examine a text carefully without needing to ascribe to the author the intention of hiding something. Thamus speaks about a context of learning and the fact that students "will hear many things without being properly taught" (275a). While Thamus' skepticism seems to arise from the temptation for students to read a lot and think they have understood without examining the subject matter carefully, it is not clear that a careless student might not just as well pick up lots of hearsay (i.e., spoken rather than written information) and thereby give the appearance of wisdom rather than being truly wise. This confirms Socrates' earlier reminder that it is not writing per se which is problematic, but bad writing. Similarly, it is not learning from written texts which is harmful, but any learning that remains on a superficial level and accumulates rather than examines knowledge. Particularly striking are therefore Thamus' formulations which bring up associations with Socrates: the students "will imagine that they have come to know much while for the most part they will know nothing" (275b) - in other words, unlike Socrates, they do not know that they know nothing.

The critique of writing as presented by Thamus and Socrates is certainly connected to Socrates' refusal to write his philosophical ideas down, as interpreters have repeatedly pointed out. Yet it should also be noted that the objections raised by Thamus confirm Socrates' ideas about teaching. Against the sophists with whom he critically engages in the Phaedrus, Socrates emphasizes that the process of learning does not consist in accumulating knowledge, be it presented in writing or speech, but in questioning the traditional conceptions in and through dialogue. What appears to be true needs to be questioned regarding its actual truth.

This emphasis is confirmed in a peculiar passage which occurs between Thamus' objections (as reported by Socrates) and Socrates' arguments. Phaedrus shows a strange reaction to the myth of Theuth; he states: "Socrates, you are very good at making up stories from Egypt or wherever else you want!" (275b). There is no need to consider this reaction or Socrates' full response here; important, however, is Socrates' final point that Phaedrus seems 
to be concerned with "who is speaking and where he comes from" when he should really "consider whether what he says is right or wrong" (275c). This passage is usually ignored in the literature, especially by the esoteric readings; yet it constitutes a significant corrective or at least supplement to the critique of writing. Just as Socrates, before telling the myth of Theuth, had already emphasized that it is not writing as such which is good or shameful, he now reminds us that it should not matter who the speaker is and where he is coming from, but whether the statements are true or not. This should hold for any logos; especially in the case of written speech, where we might be unclear or mistaken about the author and where he or she is coming from, the question about the truth of what is being said is the only significant factor. We are thus receiving a reminder to read carefully and examine what we are being told regarding whether it strikes us as right or convincing. When considering the arguments brought forth by Theuth, Thamus, and Socrates, this also means that we must not take Socrates' arguments as conclusive. It is our task to ask which statements are right.

It will thus also prove important to return to Theuth's original arguments; yet we will first follow the course of the dialogue a bit further and consider Socrates' objections which have been widely discussed in the literature, especially by the esoteric approaches, albeit in a one-sided fashion. In particular, the second objection has received much more attention than the first. In his first objection, Socrates starts from the similarity between painting and writing. This is an interesting moment because it evokes the famous passage from the Republic, Book 10, in which a painting is said to be the copy of a copy - the painted bed a copy of the wooden bed which is presented as a copy of the Form of the bed -, thus having "no grasp of the truth" (Rep. 600e). It would lead us too far away from our topic of writing to assess this difficult passage here. Suffice it to say that there are many reasons for concluding that the critique of painting in the Republic, which might seem even more straightforward than the critique of writing in the Phaedrus, is in fact equally complex. Interpreters often point to Plato's inconsistency since he lets the poets be banned from the polis yet appreciates and uses poetry and myth. For some textual evidence concerning the complex status of art, one might point to the passage from the Republic where Socrates states that poetry should be allowed to "return from exile when it has successfully defended itself," and that we would certainly all benefit if this was the case (Rep. 607d). Alternatively, the Phaedrus could be brought up where the mania of the muses is a divine gift because art is certainly not a matter 
of mere technique (and in that sense, not merely a copy of a copy!). In any case, what emerges is the ambiguity of painting rather than a straightforward reason for rejecting it.

As he explains his first objection, Socrates does not simply relate writing to painting, but focuses on a specific feature of both: when questioned, written or painted works remain silent. More precisely, they repeat the same thing again and again. This feature of repeatability is significant because it could be used to define the object at stake here, namely, a work (be it a written work or an artwork). A work is an object which stays self-same and repeats the same 'message.' As stated before, this characteristic could even be considered the strength of a work; it has the ability to stand in itself and "signify just that very same thing forever" (275d). Socrates says that this feature of the work is frustrating when we want to learn more from the work; yet we might wonder whether this frustration could lead to the realization that it is a different kind of learning which is called for here: a critical engagement with the work rather than an expectation to receive complete and final answers.

The features of the work that emerge from the first objection are confirmed by Socrates' second objection, and especially by the initial part of the objection which the esoteric approaches tend to neglect. The written speech "rolls about everywhere," like a ball, like an object (275e). It "rolls about" because it has a certain materiality and, in that sense, resembles a spatio-temporal object. The written text can be taken places - like the speech of Lysias under Phaedrus' cloak. It can be stored up, even for generations to come. Yet indeed, the text is accessible to everybody who finds it, and there are definite dangers in this. The most precarious of these dangers are of a political nature, and in that sense, Strauss' focus on the political appears justified. However, from a more strictly Platonic as well as from a contemporary perspective, ${ }^{26}$ we might wonder whether the dangers concern less the persecution of the writer than the realm of political propaganda more generally.

Yet it should also have become obvious that its material nature strengthens the written text. By way of the written speech, Lysias is (somewhat) present, as Socrates points out. Through the written dialogues, Plato and Socrates are in some sense present for us. Theuth is thus right to be proud of his invention: writing is a great reminder. Perhaps it even makes us

\footnotetext{
${ }^{26} \mathrm{I}$ have especially Emmanuel Levinas in mind here who maintains that the political state realizes itself through works; therefore, works are precarious: "From the work I am only deduced and am already ill-understood, betrayed rather than expressed" (TI, 176/151). Concerning the Platonic nature of Levinas's concept of a work, see my [removed for blind review]
} 
wiser; Theuth - in Socrates' presentation of Theuth - does not spell out how the new invention would make the Egyptians wiser, but we can imagine what he may have in mind. Facts, insights, stories and discoveries can be recorded and shared. It has even been argued that the emergence and development of philosophy in ancient Greece was dependent on the possibility of writing. ${ }^{27}$ The systematic and logical development of thought certainly benefits from being recorded.

Writing thus proves an ambiguous phenomenon, a true pharmakon (as both Theuth and Thamus call it) in both senses: remedy and poison. The Greeks, perhaps unlike ourselves, were able to think this tension as necessary and inherent in the phenomenon. ${ }^{28}$ Pharmakon is not at all what we would call a homonym, or a term for two fundamentally different meanings. Ascribing ambiguity to the phenomenon of writing does not just mean that writing can be good or bad, helpful or harmful. It means that the very materiality which sustains and strengthens the written text at the same time makes it vulnerable. Or, to bring out the precarious nature of the written text more clearly, the self-sufficiency of the written text makes it possible for the text to close itself off, as it were. Being self-enclosed, the written text does not protest when being misread, but repeats the same message over and over again.

At the end of the discussion about writing there arises what might appear to be the most important objection to the reading attempted here: Socrates states that there is another kind of discourse which is "by nature better and more capable," namely, the discourse "that is written down, with knowledge, in the soul of the listener" (276a). There might be different ways to make sense of the expression "better and more capable." I suggest, partly in light of the earlier statement that writing is not shameful, to read "better" not as an ethical category (because ethical categories require a different kind of discussion), but as a pragmatic description, closely related to the other attribute: "more capable." Oral speech is capable of certain accomplishments - especially in terms of responsivity, clarification, and discussion which the written text fails to deliver. More precisely, the written text throws more responsibility on us, the readers: we need to respond to the challenge of the written text.

\footnotetext{
${ }^{27}$ Vernant (1982).

${ }^{28}$ Heidegger points this out in relation to the term deinon which is similar to pharmakon because it can mean "terrible" as well as "wonderful:" "The Greek word deinon has that uncanny ambiguity with which the saying of the Greeks traverses the opposed con-frontations [Aus-einander-setzungen] of Being" (IM, 159).
} 
Yet what about the strange formulation that the "living discourse" is that which is "written down (graphetai), with knowledge, in the soul of the listener" (276a)? The esoteric readings should certainly attend to this formulation since it is a crucial part of the critique of writing, occurring as Socrates is most critical of the written text, it seems. The Tübingen School and Szlezák in particular find themselves in the awkward position of having to read the statement as a mere metaphor or flawed expression (e.g., Szlezák, PSP, 10). But as Strauss reminds us, there are good reasons to assume that nothing is arbitrary in a Platonic dialogue, and especially not in the Phaedrus where it is stated that "every logos must be put together like a living creature, with a body of its own“ (264c). The formulation should thus be taken seriously; perhaps Plato is indeed indicating that there is a mutual dependence between oral and written speech, or a kind of circularity. As pointed out above, the written text is not entirely helpless, but has its own strength with which it can help discourse to become more stable in space and time. Yet, in turn, the written text needs to be revived by discussion and debate; hence the circularity.

Benardete attends specifically to the passage about the speech as written in the soul. He points out that the same formulation is repeated (278a), thus making it even more obvious that Plato is not being sloppy here. When Benardete states that "what began in opposition ends up in an amalgam" and that the "ambiguous nature of writing is maintained to the end" $(R M P, 191)$, I agree with the second, but not with the first statement. Ambiguity does not mean amalgamation; the challenge of ambiguity is that the conflicting elements cannot be brought to a synthesis. Benardete thus confirms the ambiguity of writing, but runs the risk of blurring the distinctions between oral speech and writing, especially when he softens the critique of writing by stating that the "defectiveness of writing seems to be no more or less than the defectiveness of any human being" (RMP, 189). Against such a statement, the essential distinction between oral and written speech needs to be maintained and makes the critique of writing valuable.

In conclusion, the esoteric approaches have proven to be based on one-sided readings of the critique of writing. The Tübingen School in particular tends to read the critique of writing as demanding a dismissal of writing - a conclusion which requires disregarding other parts of the Phaedrus before and even within the critique of writing. Leo Strauss, in contrast, does not consider the critique to result in general problems with writing, but rather, in the possibility of hiding messages within the text and between the lines, as it were. He thus 
stresses certain advantages of writing, but not really those possibilities of writing which follow from other parts of the passage in question, such as Theuth's arguments.

Both the Tübingen School and Straussians focus on the author and his intentions, in problematic ways, as we have seen. Here, Socrates' reminder needs to be taken very seriously: the point is not who speaks, but whether what they say is true. Yet the real difficulty lies in finding out what is being said. This is where the esoteric approaches are absolutely right in emphasizing that we must not take Socrates' statements to represent Plato's views. Nor must we take Socrates' more emphatic statements to be his final word. It is indeed important to consider carefully the dialogue setting and the other interlocutors (yet mostly through their presentation within the dialogues). Even more important is the insistence of the esoteric approaches to read Plato on several levels. What these levels are should not, to my mind, be determined by focusing on the author and his potential aim of hiding something, but rather, should be determined by the phenomenon in question and the different statements within the dialogue about this phenomenon. Concentrating on the phenomenon makes the interpretation much less speculative than a focus on the author's intentions and secrets.

Furthermore, the focus on the written text is true to Plato's approach in this text since the questions of whether the written text helps memory and wisdom and whether the written text rolls about everywhere are under discussion here. The passage which is regularly taken to point to the author in fact contains a strange phrase. Socrates says that the written text "always needs its father's support" (275e). Would it not be more appropriate to say that the text would have needed its father's support, or that the text is lost because it cannot have its father's support? If the text "always needs" this support, it is conceivable that this role can be taken up by somebody who is not the author of the text. Perhaps the text calls on us, the readers, to engage with it and revive it? Might not that which the text "always needs" be interpretation, discussion and dialogue? The fact that the text signifies the same thing over and over again means that it looks for its readers, even though they might be absent in a given moment, and that it is able to signify in this way despite the absence of the author.

Where does this conclusion leave the Platonic dialogues, or what conclusions does the critique of writing have for the status of the dialogues? Is Strauss right to conclude that the critique of writing does not apply to them because they are as flexible as oral discourse, or do we still face the problem of the Tübingen School that the dialogues are simply what we are left with, despite all the flaws of the written text? Both these answers have proven 
dissatisfying, the first because it disregards the essential difference between writing and speech, the second because it cannot methodologically justify the compromise it is forced into. If the diagnosis of the ambiguity of writing is convincing, we could conclude that the Platonic dialogues bring out this ambiguity more explicitly than other texts (e.g., through the different voices, settings, myths, and the explicit discussion of writing). Drew Hyland, although not explicitly concluding that writing has an ambiguous character, makes a very helpful suggestion concerning the relation between the dialogues and the critique of writing. He maintains that "Plato thought he had discovered in the dialogue form a mode of writing that would enable him to take the risk of writing, despite the qualified efficacy of the objections against it." ${ }^{29}$ 'Taking the risk' is a very apt description because it shows that the risk cannot be ruled out or resolved; it is merely possible to take certain measures for facing the risk. However, the expression 'risk' makes it difficult to see the strength of the written text; 'ambiguity' is therefore the preferable expression for the interpretation provided in the current article.

We can thus conclude that the written Platonic dialogues, which thematize the phenomenon of writing, are able not only to face the ambiguity of writing, but to disclose this very ambiguity. Since the Phaedrus examines the possibilities and shortcomings of the written text, it holds an essential role within the Platonic corpus, as the esoteric approaches rightly claim. Yet the need to read carefully arises from the ambiguity of the written text, not from the author's intentions of hiding something. Ambiguity, in the sense described here, allows taking the objections against the written text seriously while still acknowledging Theuth's excitement about his invention. Furthermore, it allows attributing the risks and the strengths to one and the same phenomenon: writing in its ambiguity.

Tanya Staehler

University of Sussex

\footnotetext{
${ }^{29}$ Hyland (2008), p. 132.
} 


\section{Bibliography:}

Batnitzky, L. 2006. Leo Strauss and Emmanuel Levinas. Philosophy and the Politics of Revelation. Cambridge: Cambridge University Press. DOI: 10.1017/CBO9780511499050.

Benardete, S. 1991. The Rhetoric of Morality and Philosophy. Plato's Gorgias and Phaedrus. Chicago: The University of Chicago Press. [cited as RMP]

Gadamer, H.-G. 1968. 'Platons ungeschriebene Dialektik'. in H.-G. Gadamer \& W. Schadewaldt (eds.), Idee und Zahl. Studien zur platonischen Philosophie. Heidelberg: C. Winter Universitätsverlag: 9-30.

Gaiser, K. 1968. Platons ungeschriebene Lehre. Stuttgart: Klett-Cotta.

Gaiser, K. (ed.), 1969. Das Platonbild. Zehn Beiträge zum Platonverständnis. Hildesheim: Olms.

Gaiser, K. 1980. 'Plato's Enigmatic Lecture on the Good'. Phronesis 25, 1: 5-37.

DOI: $10.1163 / 156852880 X 00025$.

Hegel, G.W.F. 1986. Lectures on the History of Philosophy. in Werke, ed. E. Moldenhauer \& K. M. Michel. Frankfurt a. M.: Suhrkamp, vol. 19.

Heidegger, M. 2000. Introduction to Metaphysics. G. Fried \& F. Polt, Trans. New Haven: Yale University Press. [cited as: IM]

Hyland, D. 2002. 'Against a Platonic 'Theory' of Forms'. in W.A. Welton (ed.), Plato's Forms. Varieties of Interpretation. Oxford: Lexington Books: 257-272.

Hyland, D. 2008. Plato and the Question of Beauty. Bloomington: Indiana University Press.

Kauffmann, C. 1997. Leo Strauss zur Einführung. Hamburg: Junius.

Kauffmann, C. 2008. “'Rede' und 'Tat' im Platon-Bild von Leo Strauss”. in C. Kauffmann \& A. Eckl (eds.), Politischer Platonismus. Würzburg: Königshausen \& Neumann: 87-102.

Krämer, H.-J. 1959. Arete bei Platon und Aristoteles. Heidelberg, AHAW.

Levinas, E. 1969. Totality and Infinity, A. Lingis, Transl. Pittsburgh: Duquesne University Press. [cited as TI]

Rosen, S. 1987. Plato's Symposium, 2nd ed. New Haven: Yale University Press.

Rosen, S. 1995. Plato's Statesman: The Web of Politics. New Haven: Yale University Press.

Rosen, S. 2008. Plato's Republic: A Study. New Haven: Yale University Press.

Schleiermacher, F. 1969. “"Einleitung' zu 'Platons Werke””. in Gaiser: 1-32.

Szlezák, T.A. 1985. Platon und die Schriftlichkeit der Philosophie. Berlin: de Gruyter. [cited as PSP] 
Strauss, L. 1964. The City and Man. Chicago: Rand McNelly. [cited as CM]

Strauss, L. 1973. Persecution and the Art of Writing. Westport: Greenword Press. [cited as PAW]

Strauss, L. 1975. The Argument and the Action of Plato's Laws. Chicago: The University of Chicago Press. [cited as AAPL]

Strauss, L. 1983. Studies in Platonic Political Philosophy. Chicago: Chicago University Press, 1983. [cited as SPP]

Vernant, J.-P. 1982. The Origins of Greek Thought. London: Methuen.

Villers, J. 2005. Das Paradigma des Alphabets. Platon und die Schriftbedingtheit der Philosophie. Würzburg: Königshausen und Neumann. 